\title{
MYT1L Gene
}

National Cancer Institute

\section{Source}

National Cancer Institute. MYT1L Gene. NCI Thesaurus. Code C82897.

This gene is involved in transcriptional regulation and neuronal development. 